\title{
Isolation and Purification of Bromelain from Waste Peel of Pineapple for Therapeutic Application
}

\author{
Iara Rocha Antunes Pereira Bresolin ${ }^{1}$, Igor Tadeu Lazzarotto Bresolin ${ }^{2}$, Edgar Silveira ${ }^{3}$, \\ Elias Basile Tambourgi ${ }^{1}$ and Priscila Gava Mazzola ${ }^{4 *}$ \\ ${ }^{1}$ Faculdade de Engenharia Química; Universidade Estadual de Campinas; Campinas - SP - Brasil. ${ }^{2}$ Departamento \\ de Ciências Exatas e da Terra; Universidade Federal de São Paulo; Diadema - SP - Brasil. ${ }^{3}$ Instituto de Genética e \\ Bioquímica; Universidade Federal de Uberlândia; Uberlândia - MG - Brasil. ${ }^{4}$ Faculdade de Ciências Médicas; \\ Universidade Estadual de Campinas; Campinas - SP - Brasil
}

\begin{abstract}
The aim of this work was to isolate and purify bromelain extracted from the pineapple peel by ammonium sulfate precipitation (40-80\%), followed by desalting and freeze-drying with a $75 \%$ activity recovery and 2.2 fold increased specific activity. Ion exchange chromatography on DEAE-Sepharose was able to separate the polysaccharides from the enzyme, which was recovered in the elution step, maintaining its enzymatic activity. The batch adsorption of bromelain was evaluated in terms of total protein and enzymatic activity using Langmuir and Langmuir-Freundlich models. Results showed that the process could be suitable for the recovery and purification of the enzyme, maintaining its specific activity.
\end{abstract}

Key words: Bromelain, pineapple peel, downstream processing, waste, therapeutic applications, enzymatic activity

\section{INTRODUCTION}

Pineapple is considered the third most important fruit in the world with a projected production of 18.7 million tons for 2014 (FAO 2005). Besides the fruit consumption in natura, pineapple is also processed in order to obtain canned slices, chuncks, crush and juice, which generates wastes such as peel, stem and centrifuged solids (from juice production) and corresponds to $35-40 \%$ of the pineapple mass (Bartholomew 2003). Since these by-products have a low commercial value, they are directly returned to the fields as soil amendment, or processed in order to obtain bran used for cattle feed (Bartholomew 2003). However, these wastes are rich in the enzyme bromelain that could be recovered and purified in order to generate a product with a higher aggregate value.

Bromelain is a generic name given to proteolytic enzymes found in vegetable tissues such as peel, stem, fruit and leaves of the Bromeliaceae family, including pineapple (Ananas comosus). The enzyme found in pineapple stem (EC 3.4.22.32) is sulphydrylic and the sulphydryl group is essential to the proteolytic activity (Bartholomew 2003). The one found in pineapple fruit (EC 3.4.22.33) is an acidic protein, and its isoelectric point $(\mathrm{pI})$ is 4.6, determined by isoelectric focusing (IEF) and irreversible conformational changes occur at $\mathrm{pH}$ values higher than 10.3 (Hale 2005).The main advantages of using pineapple proteases, when compared with other plant proteases, is that the enzyme is not present in the early stages of fruit development, but its level increases rapidly,

*Author for correspondence: pmazzola@fcm.unicamp.br 
keeping high until maturity, in which a small decrease occurs (Maurer 2001). Despite the decline in proteolytic activity during maturation, the pineapple is the unique fruit that has relatively high protease concentration in the matured stage. In other fruits, such as fig and papaya, high levels of ficin and papain are only found when the fruits are green, and as the fruits become mature, the protease concentration virtually disappears (Bartholomew 2003).

Due to its proteolytic activity, bromelain has been extensively used in therapeutic applications in several animal models (Ahle 1987; Bahde 2007; Bhui et al. 2009). A wide range of therapeutic benefits have been attributed to bromelain due to its action as therapeutic target in inflammation, autoimmunity and allergy, as well as the reversible inhibition of platelet aggregation, bronchitis relief, improved recovery after surgical traumas, and enhanced absorption of drugs, particularly of antibiotics (Kelly 1996; Murakawa 2002; Roep 2002; Secor 2009). Enzymatic debridement of necrotic tissues from ulcers, burn wounds and frostbite eschar as well as anti-proliferative and anti-metastatic effects in tumor models have been also studied (Ahle 1987; Napper et al. 1994; Bhui et al. 2009).

To achieve the required characteristics for pharmaceutical usage, many approaches have been used to increase the purity and specific activity of bromelain from pineapple peel, stem and fruit. These include liquid-liquid extraction procedures (Rabelo et al. 2004; Badu 2008; Ketnawa 2010; Ferreira et al. 2011), ethanol, polyethyleneglycol or ammonium sulphate precipitation (Singh 2004; Devakate et al. 2009; Silva et al. 2010; Gautam et al. 2010; Soares et al. 2011), and polishing techniques, such as ion exchange and affinity chromatography (Harrach et al. 1998; Singh 2004; Devakate et al. 2009; Silveira 2009; Gautam et al. 2010), followed by freeze-drying for storage ends (Maurer 2001; Devakate et al. 2009). In the literature, however, there is a lack of protocols aiming at bromelain recovery and purification from by-products of food industry such as pineapple peel.

Thus, the present work aimed to study the purification of bromelain from pineapple waste peel for use in dermatological bases for therapeutic applications. Since high levels of degree of purity and specific activity of the enzyme are required, a complete downstream processing is proposed and discussed, including the bromelain extraction from pineapple peel, ammonium sulphate precipitation, desalting, freeze drying and ion exchange chromatography on DEAE-Sepharose with an adsorption study in terms of total protein and activity.

\section{MATERIALS}

\section{Plant material}

The peel of pineapples (Ananas comosus), variety "Pearl", used in this study was kindly donated by a horticultural industry (Campinas, SP, Brazil).

\section{Chemicals}

A commercial stem bromelain (EC 3.4.22.32) lyophilized powder was purchased from Sigma (USA) and used as standard in the experiments performed. The DEAE-Sepharose, crystalline bovine serum albumin (BSA), azocasein, sodium phosphate dibasic, citric acid, and potassium phosphate were acquired from Sigma (USA). Tris (hydroxymethyl amino methane) (Tris) was purchased from Merck (Germany). Trichloroacetic acid (TCA) was acquired from Synth (Brazil). Acrylamide, bis-acrylamide, sodium dodecyl sulfate (SDS), and dithiotrietol used in SDS-PAGE analysis were provided by Bio-Rad (USA). The electrophoresis calibration kit for the determination of molecular mass (Phosphorylase b, $97 \mathrm{kDa}$; Albumin, $66 \mathrm{kDa}$; Ovalbumin, $45 \mathrm{kDa}$; Carbonic anhydrase, $30 \mathrm{kDa}$; Trypsin inhibitor, $20.1 \mathrm{kDa} ; \quad \alpha$-Lactalbumin, $14.4 \mathrm{kDa}$ ) was purchased from GE Healthcare (USA). The water used for preparing the buffers and solutions was ultrapure (Milli-Q System, Millipore, USA). All other chemicals were of analytical reagent grade.

\section{METHODS}

\section{Extraction and lyophilization of bromelain from pineapple peel}

The pineapple peel was grinded using a domestic juicer without water or buffer and the contents were centrifuged at $8000 \times \mathrm{g}$ at $4^{\circ} \mathrm{C}$ for $30 \mathrm{~min}$. The supernatant was cooled to $4^{\circ} \mathrm{C}$ and the proteins were precipitated using ammonium sulfate in the range of 40-80\% saturation (Devakate et al. 2009). The salt was slowly added to the extract under constant agitation and, after the complete salt addition, it remained under stirring for $30 \mathrm{~min}$ at $4^{\circ} \mathrm{C}$. The resulting suspension was centrifuged at $8000 \times \mathrm{g}$ at $4^{\circ} \mathrm{C}$ for $15 \mathrm{~min}$. The supernatant was 
discarded and the precipitate was dissolved in a minimum volume of a $25 \mathrm{mM} \mathrm{L} \mathrm{L}^{-1}$ potassium phosphate buffer at $\mathrm{pH}$ 7.0. This sample was desalted on a gel filtration column (PD-10, Sephadex G-25 M, GE Healthcare, USA), frozen in liquid nitrogen and lyophilized according to the procedure described by the manufacturer (Lioalfa 6-80 Telstar, Spain).

\section{Purification of bromelain by ion exchange chromatography}

The chromatographic procedure was carried out using a low pressure chromatographic system (Gilson, France) at room temperature at a flow rate of $0.5 \mathrm{~mL} \mathrm{~min}{ }^{-1}$ (superficial velocity of 38.2 $\mathrm{cm} \mathrm{h}^{-1}$ ). The ion exchange media DEAESepharose was suspended in water, degassed, and packed without compression into columns (10.0 $\mathrm{cm} \times 1.0 \mathrm{~cm}$ I.D., GE Healthcare, USA) to give a bed volume of $1.0 \mathrm{~mL}$. The columns were equilibrated with loading buffer. In order to study the influence of the buffer on enzyme adsorption, the following loading buffers were used: $25 \mathrm{mM} \mathrm{L}^{-}$ ${ }^{1}$ Mcllvaine (sodium phosphate dibasic and citric acid), $\mathrm{pH}$ 5.0; $25 \mathrm{mM} \mathrm{L}^{-1}$ potassium phosphate, $\mathrm{pH}$ 7.0 and $25 \mathrm{mM} \mathrm{L}^{-1}$ Tris- $\mathrm{HCl}, \mathrm{pH}$ 9.0. A prepurified freeze-dried bromelain solution $(0.3 \mathrm{mg}$ $\mathrm{mL}^{-1}$ ) was prepared for each buffer to be used as feed in the column. After the sample injection, the column was washed with the loading buffer until the absorbance values at $280 \mathrm{~nm}$ were close to zero. Elution was performed increasing the ionic strength of the loading buffer (addition of $1.0 \mathrm{~mol} \mathrm{~L}^{-1} \mathrm{NaCl}$ ). After each experiment, the column was regenerated by using $50 \mathrm{mM} \mathrm{L}^{-1}$ $\mathrm{NaOH}$, followed by ultrapure water. Throughout the experiment, fractions of $2.0 \mathrm{~mL}$ were collected, quantified in terms of total protein and polysaccharides by Bradford (Bradford 1976) and Dubois (Dubois et al. 1956) methods, respectively. The samples situated on the peaks of proteins were pooled and the bromelain activity was measured by the azocasein method (Sarath et al. 1989) and analyzed by SDS-PAGE under denaturing and non-reducing conditions.

\section{Batch adsorption of bromelain on agarose- DEAE gel}

In order to determine the isotherm of bromelain adsorption on agarose-DEAE gel, experiments were carried out (in duplicate) at $25^{\circ} \mathrm{C}$ in stirred tanks batch adsorption (Eppendorf tubes) containing $50 \mu \mathrm{L}$ of gel as described in the literature for other proteins (Bresolin et al. 2009; Bresolin et al. 2010; Bresolin et al. 2011). Briefly, the agarose-DEAE gel was equilibrated with $25 \mathrm{mM} \mathrm{L}^{-1}$ potassium phosphate buffer at $\mathrm{pH} 7.0$ and then $1.0 \mathrm{~mL}$ aliquots of bromelain solutions (total protein from 0.4 to $14.2 \mathrm{mg} \mathrm{mL}^{-1}$; enzymatic activity from 0.3 to $8.2 \mathrm{U} \mathrm{mL}^{-1}$ ) were added to the tubes. The tubes were agitated end-over-end at 10 $\mathrm{rpm}$ for $1 \mathrm{~h}$ in order to establish the equilibrium. After this, protein equilibrium concentration $\left(\mathrm{C}^{*}\right)$ was determined by the Bradford method (Bradford 1976) and enzymatic activity equilibrium (A*) was determined using the azocasein method (Sarath et al. 1989), both for the liquid phase. The mass of protein adsorbed per volume of gel $(\mathrm{mg}$ $\mathrm{mL}^{-1}$ of gel), $\mathrm{Q}_{\mathrm{TP}}{ }^{*}$, and the activity adsorbed per volume of gel $\left(\mathrm{U} \mathrm{mL} \mathrm{mL}^{-1}\right.$ of gel), $\mathrm{Q}_{\mathrm{A}}{ }^{*}$ were respectively calculated as the difference between the amount of protein, or activity added and those remaining in the liquid phase after equilibrium divided by the adsorbent volume. The plots of $\mathrm{Q}_{\mathrm{TP}}{ }^{*}$ versus $\mathrm{C}^{*}$ and $\mathrm{Q}_{\mathrm{A}}{ }^{*}$ versus $\mathrm{A}^{*}$ were the equilibrium isotherms. The Langmuir parameters (Eq. (1)), and the Langmuir-Freundlich (Eq. (2)) models, presented in Table 1 , were fitted to the experimental data, using the nonlinear LevenbergMarquardt iterative fitting method of Origin ${ }^{\circledR}$ software (Microcal, USA).

Table 1 - Isotherm adsorption models used to fit the experimental data of total protein and activity.

\begin{tabular}{cccc}
\hline Model & Total Protein & Activity & \\
\hline Langmuir & $\mathrm{Q}_{\mathrm{TP}} *=\frac{\mathrm{Q}_{\mathrm{m}} \mathrm{C}^{*}}{\mathrm{~K}_{\mathrm{d}}+\mathrm{C}^{*}}$ & $\mathrm{Q}_{\mathrm{A}} *=\frac{\mathrm{Q}_{\mathrm{mA}} \mathrm{A}^{*}}{\mathrm{~K}_{\mathrm{dA}}+\mathrm{A}^{*}}$ & Eq. (1) \\
Langmuir-Freundlich & $\mathrm{Q}_{\mathrm{TP}} *=\frac{\mathrm{Q}_{\mathrm{m}}\left(\mathrm{C}^{*}\right)^{\mathrm{n}}}{\mathrm{K}_{\mathrm{dLF}}+\left(\mathrm{C}^{*}\right)^{\mathrm{n}}}$ & $\mathrm{Q}_{\mathrm{A}}^{*}=\frac{\mathrm{Q}_{\mathrm{mA}}\left(\mathrm{A}^{*}\right)^{\mathrm{n}_{\mathrm{A}}}}{\mathrm{K}_{\mathrm{dLF}}+\left(\mathrm{A}^{*}\right)^{\mathrm{n}_{\mathrm{A}}}}$ & Eq. (2) \\
\hline
\end{tabular}

The parameters of Eq. (1) and Eq. (2) are described below: $\mathrm{Q}_{\mathrm{m}}$ is the maximum protein binding capacity; $\mathrm{Q}_{\mathrm{mA}}$ is the maximum activity binding capacity; $\mathrm{K}_{\mathrm{d}}$ and $\mathrm{K}_{\mathrm{dA}}$ are the dissociation 
constants; $\mathrm{K}_{\mathrm{dLF}}$ and $\mathrm{K}_{\mathrm{dLFA}}$ are the apparent dissociation constants; and $\mathrm{n}$ is the LangmuirFreundlich coefficient, which indicates the presence $(n>1)$ or absence $(n<1)$ of cooperativity.

\section{Bromelain activity}

The protease activity was assayed using the azocasein method (Sarath et al. 1989) by monitoring the rate of release of TCA soluble-azocoupled peptides from azocasein at $440 \mathrm{~nm}$. The reaction mixture contained $0.2 \mathrm{~mL} 2 \%$ azocasein $(\mathrm{w} / \mathrm{v})$ and $0.2 \mathrm{~mL}$ enzyme appropriately diluted in $25 \mathrm{mmol} \mathrm{L}^{-1}$ potassium phosphate buffer at $\mathrm{pH}$ 7.0. The reaction was started by the addition of the enzyme aliquot. After incubating at $37^{\circ} \mathrm{C}$ for 10 min, the reaction was arrested by adding $1.2 \mathrm{~mL}$ of $5 \%$ TCA $(\mathrm{w} / \mathrm{v})$. The test mixture was centrifuged at $6000 \times \mathrm{g}$ for $10 \mathrm{~min}$ to collect the supernatant containing TCA-soluble azo-coupled peptides. The absorbance of the supernatant at $440 \mathrm{~nm}$ was measured against the corresponding blank without enzyme. One unit of protease activity was defined as the amount of enzyme required to produce an absorbance change of 1.0 in a $1 \mathrm{~cm}$ cuvette under the assay conditions.

\section{Protein determination}

The total protein content was analyzed by the Coomassie blue dye technique according to Bradford (1976) using BSA as a reference protein. The intensity of the color was measured at 595 nm.

\section{Polysaccharide determination}

The total polysaccharide present was determined by the Dubois method (Dubois et al. 1956) using glucose as standard. Yellow to orange color developed in the reaction mixture was measured at $480 \mathrm{~nm}$ and compared with the analytical curve of glucose.

\section{Sodium dodecyl sulfate polyacrylamide gel electrophoresis (SDS-PAGE)}

Protein samples (about $1 \mu \mathrm{g}$ per lane) were analyzed by SDS-PAGE in $12.5 \%$ polyacrylamide gels under denaturing and non-reducing conditions according Laemmli (1970) in a Mini-Protean III System (Bio-Rad, USA). The separation was carried out at $180 \mathrm{~V}$ in $7.5 \%$ separation gels with a $4 \%$ stacking gel. Protein bands were developed by silver staining in accordance to Morrissey (1981).

\section{RESULTS AND DISCUSSION}

\section{Extraction and Drying of Bromelain from Pineapple Peel}

Bromelain from the pineapple peel was extracted and partially purified by precipitation with ammonium sulfate in the range of $40-80 \%$ saturation, in which $75 \%$ of bromelain was recovered. This result was in accordance to Devakate et al. (2009) who recovered approximately $80 \%$ of bromelain from the pineapple fruit by ammonium sulfate in the same range of saturation. After the precipitation, the resuspended precipitate was desalted and lyophilized for storage, as recommended by Maurer (Maurer 2001). The results of enzymatic activity and total protein concentration of bromelain samples before and after the lyophilization are presented in Table 2.

The SDS-PAGE (Fig. 1) showed that the ammonium sulfate precipitation was able to partially purify the crude extract (lane 1) when compared to the sample presented in lane 2 . Bromelain from the pineapple peel had two molecular weights, approximately 20 and $30 \mathrm{kDa}$, similar to that of stem bromelain from Sigma (USA) used as a bromelain marker, which had a more intense band around $30 \mathrm{kDa}$. However, several authors characterized the fruit and stem bromelain as having molecular weights ranging from 24.5 to $37 \mathrm{kDa}$ (Ota 1972; Takahashi 1973; Wharton 1974; Silverstein 1975; Murachi 1976; Silveira 2009; Gautam 2010; Ferreira 2011). Besides the differences in the bromelain source (peel, fruit and stem), other parameters such as pineapple species, age, harvesting and size could also affect the protein and enzyme content (Bartholomew 2003).

Results presented in Table 2 showed that the specific activity increased 2.2 fold before the lyophilization (after the steps of precipitation, resuspension and desalting). When pineapple fruit extract was submitted to the same range of precipitation, but the desalting was done by dialysis, a similar increase of the specific activity was obtained by Devakate and coworkers (2009). Ammonium sulfate fractionation (15-37\%) was also used by Singh et al. 2004 to precipitate bromelain from the pineapple crown leaf with a similar increase of the specific activity achieved after this step. 


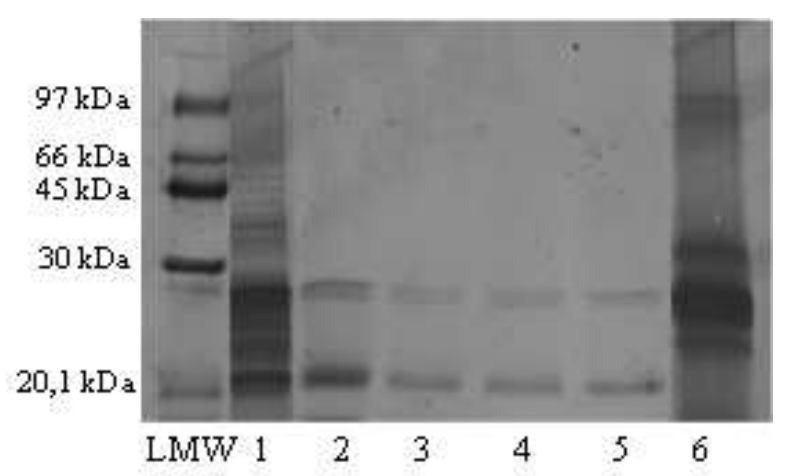

Figure 1 - SDS-PAGE analysis under denaturing and non-reducing conditions using $12.5 \%$ polyacrylamide gel. Lanes: LMW, low molecular mass marker (GE Healthcare); 1, crude extract (before purification); 2, pre-purified bromelain after ammonium sulfate precipitation (chromatography injected solution); 3-5, elution samples of chromatographies performed at $\mathrm{pH} 5.0$, 7.0, and 9.0, respectively; 6, stem bromelain marker (Sigma, USA).

Table 2 - Purification table of bromelain from pineapple peel.

\begin{tabular}{lccc}
\hline & $\begin{array}{l}\text { Crude } \\
\text { extract }\end{array}$ & Precipitation $^{a}$ Lyophilization $^{b}$ \\
\hline $\begin{array}{l}\text { Volume }(\mathrm{mL}) \\
\text { Activity } \\
\left(\mathrm{U} \mathrm{mL}^{-1}\right)^{c}\end{array}$ & 1800 & 500 & - \\
$\begin{array}{l}\text { Total activity } \\
(\mathrm{U})\end{array}$ & 0.13 & 0.35 & 0.31 \\
$\begin{array}{l}\text { Activity } \\
\text { recovery }(\%)\end{array}$ & 100 & 75 & - \\
$\begin{array}{l}\text { Total protein } \\
\left(\mathrm{mg} \mathrm{mL}^{-1}\right)^{d}\end{array}$ & 0.25 & 0.31 & - \\
$\begin{array}{l}\text { Specific activity } \\
\left(\mathrm{U} \mathrm{mg}^{-1}\right)^{e}\end{array}$ & 0.52 & 1.13 & 0.28 \\
$\begin{array}{l}\text { Purification } \\
\text { factor }\end{array}$ & 1 & 2.2 & 1.11 \\
\hline
\end{tabular}

${ }^{a}$ Refers to the desalted ressuspended precipitate (range 40$80 \%)$. ${ }^{b}$ Refers to a $1 \%$ solution (w/v). ${ }^{c}$ Bromelain activity: Determined using the Azocasein method (Sarath et al. 1989). Average standard deviation: $2.3 \%$. ${ }^{d}$ Total protein: Mass calculated from protein concentration determined according Bradford method (Bradford 1976). Average standard deviation: $1.5 \%$. ${ }^{e}$ Specific activity: Bromelain activity divided by total protein content. ${ }^{f}$ In terms of activity.

In order to compare the effect of lyophilization procedure, a $1 \%$ solution $(\mathrm{w} / \mathrm{v})$ of lyophilized commercial bromelain (Sigma, USA) was prepared and the activity and protein content were determined. Results showed that the partially purified samples of bromelain had a specific activity three times higher than the commercial sample of bromelain $\left(0.38 \mathrm{U} \mathrm{mg}^{-1}\right)$, since the commercially purchased enzyme had a higher amount of total protein $\left(1.60 \mathrm{mg} \mathrm{mL}^{-1}\right)$. The comparison was performed using the commercial stem bromelain from Sigma, since there was no pineapple peel bromelain commercially available. Lyophilization (freeze dried) aims to reduce the moisture content of the sample, which is strongly recommended for storage (Maurer 2001; Devakate et al. 2009). However, due to some activity losses during the lyophilization process, the specific activity was reduced by $5.2 \%$, similar to the activity loss of fruit bromelain reported by Devakate et al. (2009).

\section{Purification of Bromelain by Ion Exchange Chromatography}

After the partial purification of the extract from pineapple peel, the ion exchange chromatography was performed aiming to increase the bromelain specific activity. A $1.0 \mathrm{~mL}$ bed of DEAESepharose was used and the following loading buffers at $25 \mathrm{mM} \mathrm{L}^{-1}$ were evaluated: Mcllvaine, $\mathrm{pH}$ 5.0; potassium phosphate, $\mathrm{pH} 7.0$ and Tris$\mathrm{HCl}, \mathrm{pH}$ 9.0. Lyophilized bromelain was dissolved in each buffer and the resulting solution of $0.3 \mathrm{mg}$ $\mathrm{mL}^{-1}$ concentration was used as feed in the chromatography. For all the experimental conditions studied, bromelain remained adsorbed on the ion exchanger DEAE-Sepharose, which was positively charged at $\mathrm{pH}$ values studied, and could be recovered in the elution stage, since less than $4 \%$ of the total protein was detected in the washing step of the chromatographies. According to Figure 1 , the two sample protein bands in the injected material (molecular mass of approximately 20 and $30 \mathrm{kDa}$ ) were recovered in the elution step, irrespective of the $\mathrm{pH}$ and the adsorption buffer nature. This result indicated that there was no separation of these proteins in the chromatographic process. However, as bromelain comprised a group of proteolytic enzymes (not only a single enzyme), apparently these two bands were of enzyme, since the activity was maintained after elution.

Bromelain remained adsorbed on DEAESepharose probably because of the predominance of accessible negatively charged groups. Bromelain from pineapple fruit had a pI of 4.6 (Bartholomew 2003) and this result showed that the enzyme from pineapple peel also had a $\mathrm{pI}<5.0$ (the lower $\mathrm{pH}$ evaluated). The highest enrichment factor in terms of activity was achieved in the 
chromatography performed using potassium phosphate at $\mathrm{pH}$ 7.0. Corzo et al. (2012) found that the optimum $\mathrm{pH}$ values of fruit bromelain were around 7.0, using both azocasein and azoalbumin as substrates to measure the proteolytic activity.

The chromatographic fractions of the experiment carried out at $\mathrm{pH} 7.0$ were analyzed in terms of total protein and polysaccharide contents and enzymatic activity (Fig. 2) as summarized in Table 3. According to Figure 2, the chromatography was able to separate the polysaccharides (which were recovered in the washing step) from the enzyme (recovered in the elution step). The eluted bromelain was recovered with only $2.3 \%$ of the polysaccharide initially present in the lyophilized extract, thus, resulting in an increase in the specific activity.

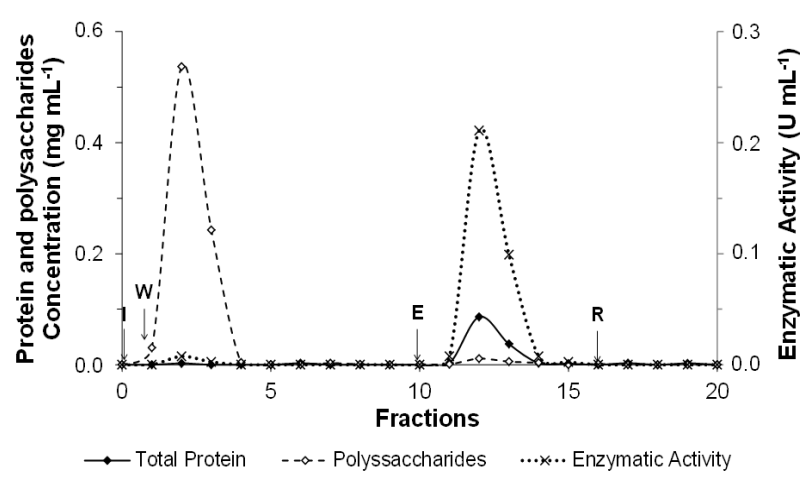

Figure 2 - Chromatogram for $1.0 \mathrm{~mL}$ of lyophilized bromelain solution $(0.3 \mathrm{mg})$ using 25 mmol L $\mathrm{L}^{-1}$ potassium phosphate buffer, $\mathrm{pH}$ 7.0 for DEAE-Sepharose gel (1.0 mL bed). I: injection, W: washing, E: elution, R: regeneration. Solid, dashed and dotted lines correspond to total protein (Bradford 1976), polysaccharides (Dubois et al. 1956) and enzymatic activity (Sarath et al. 1989).

\section{Determination Adsorption Isotherm of Bromelain}

Adsorption isotherms of protein and activity were determined by the experimental data obtained from batch adsorption experiments at $25^{\circ} \mathrm{C}$ using agarose-DEAE gel in $25 \mathrm{mM} \mathrm{L^{-1 }}$ potassium phosphate at $\mathrm{pH} \quad 7.0$ to evaluate the thermodynamic parameters, such as maximum binding capacity, dissociation constant, apparent dissociation constant, and cooperativity parameter for total protein and enzymatic activity, since less than $2.5 \%$ of polysaccharide remained adsorbed for all the experimental points (data not shown). Results were analyzed using the Langmuir and Langmuir-Freundlich models (Table 4). A comparison between the experimental and theoretical profiles is depicted in Figure 3A.

Results presented in Table 4 showed that the Langmuir and Langmuir-Freundlich models described satisfactorily bromelain adsorption data, in terms of total protein content. The presence of positive cooperativity $(\mathrm{n}=1.23)$ in accordance with the fitted cooperativity parameter of the Langmuir-Freundlich model, could be originated due to a heterogeneous nature of the adsorption (multipoint interactions or surface heterogeneity), in which one adsorbed bromelain molecule tended to favor the adsorption of other bromelain molecules (Johnson 1995).

The bromelain maximum adsorption capacity $\left(\mathrm{Q}_{\mathrm{m}}\right)$ on agarose-DEAE ranged from 15.6 to $17.0 \mathrm{mg}$ $\mathrm{mL}^{-1}$ (46.7 to $50.9 \mathrm{mg} \mathrm{g}^{-1} ; 1 \mathrm{~mL}$ gel $=0.33 \mathrm{~g}$ according to the manufacturer). These values were of the same order of magnitude as those in experimental data reported for bromelain adsorption onto uncoated magnetic nanoparticles (MNPs) and chitosan-coated magnetic nanoparticles (CS-MNPs) adsorbents (24.0 and $48.2 \mathrm{mg} \mathrm{g}^{-1}$ ) reported by Song et al. (2011). However, these authors also attached a Red 120 dye to the CS-MNPs, which increased the bromelain binding capacity of the particles up to $102.6 \mathrm{mg} \mathrm{g}^{-1}$ due to the mixed-mode effect of different interaction mechanisms such as hydrophobic, electrostatic, and hydrogen bonds between the immobilized Red 120 and bromelain molecules. For instance, the dissociation constant $\left(\mathrm{K}_{\mathrm{d}}\right)$ value was of the order of magnitude of $10^{-5}$ mol L ${ }^{-1}$, similar to that presented for Red 120-CSMNPs (Song 2011), which indicated that DEAE could be considered a low-affinity medium for bromelain adsorption (Vijayalakshmi 1989).

Enzymatic activity isotherm data were also analyzed using the Langmuir and LangmuirFreundlich models (Fig. 3B and Table 5). A good model fit was obtained $\left(\mathrm{R}^{2}=0.993\right)$ for the Langmuir-Freundlich model. The activity maximum adsorption capacity $\left(\mathrm{Q}_{\mathrm{mA}}\right)$ on agaroseDEAE ranged from 15.7 to $18.8 \mathrm{U} \mathrm{mL}^{-1}$. These values were approximately two times higher than those obtained from the adsorption of stem bromelain in Amberlite IRA 410 ion-exchange resin reported by Silveira et al. (2009), in which the maximum adsorption capacity was $9.2 \mathrm{U} \mathrm{mL}^{-1}$ of resin using the Langmuir model. 
The dissociation constant $\left(\mathrm{K}_{\mathrm{dA}}\right)$ and apparent dissociation constant $\left(\mathrm{K}_{\mathrm{dLFA}}\right)$ for the activity were fitted as 0.23 and $0.77 \mathrm{U} \mathrm{mL}^{-1}$ in the same order of magnitude as $0.59 \mathrm{U} \mathrm{mL}^{-1}$ reported by Silveira et al. (2009).

(a)

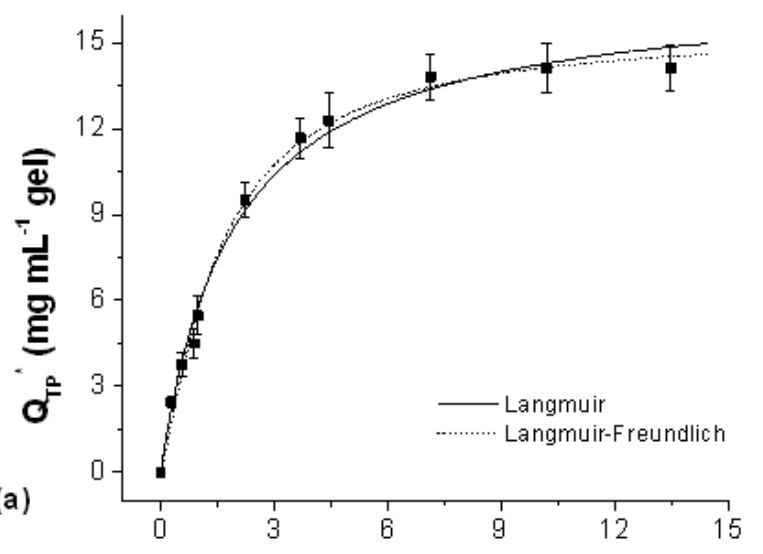

b)

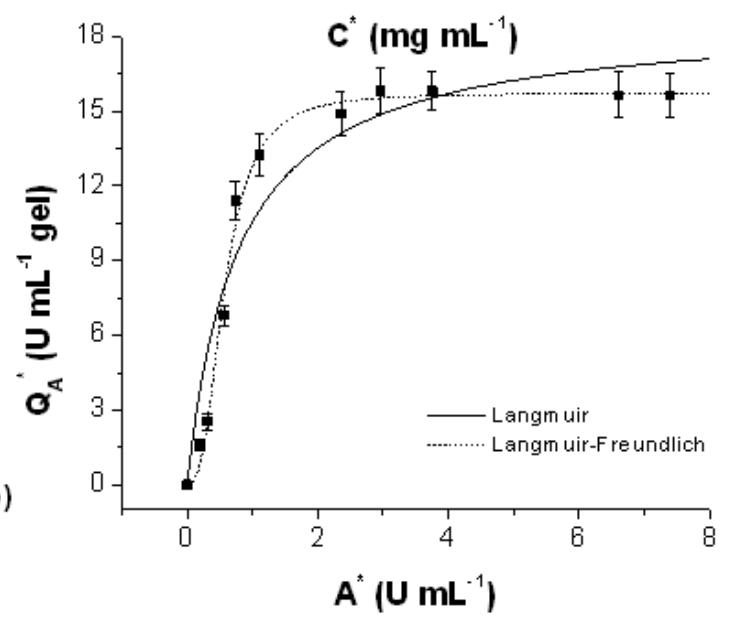

Figure 3 - Experimental adsorption isotherms of bromelain in terms of (A) total protein and (B) enzymatic activity on DEAESepharose gel using $25 \mathrm{mmol} \mathrm{\textrm {L } ^ { - 1 }}$ potassium phosphate buffer, $\mathrm{pH} 7.0$, at $25^{\circ} \mathrm{C}$. The solid and dashed lines correspond to nonlinear regression of experimental data in accordance with the Langmuir and Langmuir-Freundlich models, respectively.

The cooperativity parameter for the activity $\left(n_{A}\right)$ was $2.66 \pm 0.28$, corroborating the presence of cooperative effects described for total protein. The cooperativity depends on the nature of the macromolecule and the presence of multiple functional groups, which usually produce multiple interactions with the DEAE ligand. Attractive force caused by the lateral interactions, or protein-protein interactions that could take place besides the heterogeneous nature of the adsorption due to multipoint interactions indicated strong retention of enzyme.

\section{CONCLUSION}

Results demonstrated that it was possible to purify bromelain extracted from the pineapple peel using ammonium sulfate precipitation (40-80\% saturation), followed by desalting, freeze-dry and chromatography on DEAE-Sepharose, and the enzyme could be recovered active after all the steps performed. Chromatography was able to separate the polysaccharides from the enzyme, which was recovered in the elution step. The adjustment of the Langmuir-Freundlich model to experimental total protein and activity adsorption data showed the presence of cooperative effects between the DEAE ligand and bromelain. Thus, the downstream processing protocol presented in this work could be considered an alternative procedure of bromelain recovery from pineapple peel for therapeutic applications.

\section{ACKNOWLEDGEMENTS}

The authors gratefully acknowledge the financial support and the scholarship received from $\mathrm{CNPq}$ (Brazil).

\section{REFERENCES}

Ahle NW, Hamlet MP. Enzymatic frostbite eschar debridement by bromelain. Ann Emerg Med. 1987; 16: 1063-1065.

Babu BR, Rastogi NK, Raghavarao KSMS. Liquidliquid extraction of bromelain and polyphenol oxidase using aqueous two-phase system. Chem Eng Process. 2008; 47: 83-89.

Bahde R, Palmes D, Minin E, Stratmann U, Diller R, Haier $\mathbf{J}$ et al. Bromelain ameliorates hepatic microcirculation after warm ischemia. J Surg Res. 2007; 139: 88-96.

Bartholomew DP, Paull RE, Rohrbach KG. 1st ed. The pineapple: botany, production and uses. WallingfordUK:CABI Publishing; 2003. 
Bhui K, Prasad S, George J, Shukla Y. Bromelain inhibits COX-2 expression by blocking the activation of MAPK regulated NF-kappa B against skin tumorinitiation triggering mitochondrial death pathway. Cancer Lett. 2009; 282: 167-176.

Bradford MM. A rapid and sensitive method for the quantitation of microgram quantities of protein utilizing the principle of protein-dye binding. Anal Biochem. 1976; 72: 248-254.

Bresolin ITL, Borsoi-Ribeiro M, Caro JR, Santos FP, Castro MP, Bueno SMA. Adsorption of human serum proteins onto TREN-agarose: Purification of human IgG by negative chromatography. $J$ Chromatogr $B$. 2009; 877: 17-23.

Bresolin ITL, Fioritti RF, Bueno SMA. IgG purification by negative chromatography in amine-based ligands: A comparison of L-lysine and poly-L-lysine. Proc Biochem. 2011; 46: 2277-2285.

Bresolin ITL, Souza MCM, Bueno SMA. A new process of IgG purification by negative chromatography: Adsorption aspects of human serum proteins onto $\omega$-aminodecyl-agarose. J Chromatogr B. 2010; 878: 2087-2093.

Corzo CA, Waliszewski KN, Welti-Chanes J. Pineapple fruit bromelain affinity to different protein substrates. Food Chem. 2012; 133: 631-635.

Devakate RV, Patil VV, Waje SS, Thorat BN. Purification and drying of bromelain. Sep Purif Technol. 2009; 64: 259-264.

Dubois M, Gilles KA, Hamilton JK, Rebers PA, Smith F. Colorimetric method for determination of sugars and related substances. Anal Chem. 1956; 28: 350356.

FAO - Food and Agriculture Organization of the United Nations. Current Situation and Medium-Term Outlook for Tropical Fruits (Report). 2005. <http://www.fao.org/es/esc/common/ecg/218/en/Sit_ web_e.pdf > Last accessed: July, $4^{\text {th }} 2012$.

Ferreira JF, Santana JCC, Tambourgi EB. The Effect of $\mathrm{pH}$ on Bromelain Partition from Ananas comosus by PEG4000/Phosphate ATPS. Braz Arch Biol Technol. 2011; 54: 125-132.

Gautam SS, Mishra SK, Dash V, Goya AK, Rath G. Comparative study of extraction, purification and estimation of bromelain from stem and fruit of pineapple plant. Thai J Pharm Sci. 2010; 34: 67-76.

Hale LP, Greer PK, Trinh CT, James CL. Proteinase activity and stability of natural bromelain preparations. Int Immunopharmacol 2005; 5: 783793.

Harrach T, Eckert K, Maurer HR, Machleidt I, Machleidt W, Nuck R. Isolation and characterization of two forms of an acidic bromelain stem proteinase. J Protein Chem. 1998; 17: 351-361.
Johnson RD, Arnold FH. Multipoint binding and heterogeneity in immobilized metal affinity chromatography. Biotechnol Bioeng. 1995; 48: 437443.

Kelly GS. Bromelain: A literature review and discussion of its therapeutic applications. Altern Med Rev. 1996; 1: 243-257.

Ketnawa S, Rawdkuen S, Chaiwut P. Two phase partitioning and collagen hydrolysis of bromelain from pineapple peel Nang Lae cultivar. Biochem Eng J. 2010; 47: 205-211.

Laemmli UK. Cleavage of structural proteins during assembly of head of bacteriophage-T4. Nature. 1970; 227: 680-685.

Maurer, HR. Bromelain: biochemistry, pharmacology and medical use. Cell Mol Life Sci. 2001; 58: 12341245.

Morrissey JH. Silver stain for proteins in polyacrylamide gels: A modified procedure with enhanced uniform sensitivity. Anal Biochem. 1981; 117: 307-310.

Murachi T. Bromelain enzymes. Methods Enzymol. 1976; 45: 475-485.

Murakawa T, Yamagata H, Tsuruta H, Aizono Y. Cloning of cold-active alkaline phosphatase gene of a psychrophile, Shewanella sp., and expression of the recombinant enzyme. Biosci Biotechnol Biochem. 2002; 66: 754-761.

Napper AD, Bennett SP, Borowski M, Holdridge MB, Leonard MJ, Rogers EE et al. Purification and characterization of multiple forms of the pineapplestem-derived cysteine proteinases ananain and comosain. Biochem J. 1994; 301: 727-735.

Ota S, Horie K, Hagino F, Hashimoto C, Date H. Fractionation and some properties of the proteolytically active components of bromelains in the stem and the fruit of the pineapple plant. $J$ Biochem. 1972; 71: 817-830.

Rabelo APB, Tambourgi EB, Pessoa Jr A, Bromelain partitioning in two-phase aqueous systems containing PEO-PPO-PEO block copolymers. J Chromatogr B. 2004; 807: 61-68.

Roep BO, van den Engel NK, van Halteren AG, Duinkerken G, Martin S. Modulation of autoimmunity to beta-cell antigens by proteases. Diabetologia. 2002; 45: 686-692.

Sarath G, De La Motte RS, Wagner FW. Protease assay methods. In: Beynon RJ, Bonde JS. Proteolytic enzymes: a practical approach. Oxford: Oxford University Press; 1989, p. 25-54.

Secor Jr ER, Singh A, Guernsey LA, McNamara JT, Zhan L, Maulik N et al. Bromelain treatment reduces CD25 expression on activated CD4+ T cells in vitro. Int Immunopharmacol. 2009; 9: 340-346. 
Silva FV, Santos RLA, Fujiki TL, Leite MS, Fileti AMF. Design of automatic control system for the precipitation of bromelain from the extract of pineapple wastes. Cienc Tecnol Aliment. 2010; 30: 1033-1040.

Silveira E, Souza Jr ME, Santana JCC, Chaves AC, Porto ALF, Tambourgi EB. Expanded bed adsorption of bromelain (E.C. 3.4.22.33) from Ananas comosus crude extract. Braz J Chem Eng. 2009; 26: 149-157.

Silverstein RM, Kezdy FJ. Characterization of the pineapple stem proteases (bromelain). Arch Biochem Biophys. 1975; 167: 678-686.

Singh LR, Devi TP, Devi SK. Purification and Characterization of a Pineapple Crown Leaf Thiol Protease. Prep Biochem Biotech. 2004; 34: 25-43.

Soares P, Coelho D, Mazzola P, Silveira E, Carneiroda-Cunha MG, Pessoa Jr A et al. Studies on bromelain precipitation by ethanol, poly(ethylene glicol) and ammonium sulphate. Chem Eng Trans. 2011: 24; 979-984.
Song MM, Nie HL, Zhou YT, Zhu LM, Bao JY, Affinity adsorption of bromelain on Reactive Red 120 immobilized magnetic composite particles. Separ Sci Technol. 2011; 46: 473-482.

Takahashi N, Yasuda Y, Goto K, Miyake T, Murachi T. Multiple molecular forms of stem bromelain. Isolation and characterization of two closely related components, SB1 and SB2. J Biochem. 1973; 74: 355-373.

Vijayalakshmi MA. Pseudobiospecific ligand affinity chromatography. Trends Biotechnol. 1989; 7: 71-76.

Wharton CW. The structure and mechanism of stem bromelain: Evaluation of the homogeneity of purified stem bromelain, determination of the molecular weight and kinetic analysis of the bromelaincatalysed hydrolysis of N-benzyloxy-carbonyl-Lphenylalanyl-L-serine methyl ester. Biochem J. 1974; 143: 575-586. 